\title{
senX3-independent contribution of regX3 to Mycobacterium tuberculosis virulence
}

\author{
Dalin Rifat ${ }^{1}$, Deborah A Belchis ${ }^{2}$ and Petros C Karakousis ${ }^{1,3^{*}}$
}

\begin{abstract}
Background: Mycobacterium tuberculosis (Mtb) must adapt to various stress conditions during host infection. The two-component regulatory system (2CRS) SenX3-RegX3 is required for Mtb virulence. We showed recently that the senX3-regX3 intergenic region contains promoter activity, driving senX3-independent regX3 expression. In the current study, we tested the hypothesis that RegX3 has a SenX3-independent role in Mtb virulence. The gene expression patterns, growth, and survival of mutants containing transposon insertions in senX3 (senX3::Tn) and regX3 (regX3::Tn) were compared to those of their respective complemented strains and the isogenic wild-type parent strain during axenic growth in nutrient-rich broth, phosphate depletion, nutrient starvation, and in the lungs of BALB/C mice.

Results: regX3 expression was reduced in senX3::Tn during phosphate depletion and nutrient starvation, and expression of the phosphate-specific transport gene pstC2 was reduced similarly in senX3::Tn and regX3::Tn during phosphate depletion. Although senX3 and regX3 were each dispensable for Mtb growth in nutrient-rich broth, disruption of senX3 or regX3 caused a similar growth defect during phosphate depletion. Interestingly, senX3:: Tn, in which monocistronic regX3 expression is preserved, showed significantly higher survival relative to regX3::Tn after 7 days of nutrient starvation $(p<0.01)$, and in mouse lungs at Day $31(p<0.01)$, Day $62(p<0.01)$, and Day 124 $(p=0.05)$ after aerosol infection.
\end{abstract}

Conclusion: Our data demonstrate the specificity of the senX3-regX3 2CRS for sensing and responding to low ambient phosphate, but also raise the possibility that RegX3 may function independently of its cognate sensor histidine kinase.

Keywords: Mycobacterium tuberculosis, Specificity, Stringent response, Persistence, Virulence, Phosphate, Nutrient, Starvation, Mouse, Cross-regulation

\section{Background}

Two component regulatory systems (2CRS) comprise a sensor histidine kinase (HK) and a response regulator (RR), which sense and respond to various environmental conditions, thus promoting bacterial survival [1]. Upon detection of a specific stimulus, the HK autophosphorylates and transfers a phosphoryl group to the cognate $\mathrm{RR}$, which promotes DNA binding of the latter to initiate transcription of the appropriate adaptive response $[2,3]$. However, under certain circumstances, bacterial RR may also be phosphorylated by a noncognate HK or

\footnotetext{
* Correspondence: petros@jhmi.edu

'Department of Medicine, Johns Hopkins University School of Medicine Center for Tuberculosis Research, 1551 East Jefferson Street, Room 110, Baltimore, MD 21287, USA

${ }^{3}$ Department of International Health, Johns Hopkins Bloomberg School of Public Health, Baltimore, MD 21205, USA

Full list of author information is available at the end of the article
}

small molecule acetyl phosphate, merging different stimuli or diversifying the response to a single signal [4], or may function without being phosphorylated [5-8].

Twelve complete pairs of 2CRS and a few orphan HK and RR genes have been found in the Mycobacterium tuberculosis (Mtb) genome. SenX3-RegX3 was among the first 2 CRS to be identified in Mtb $[9,10]$. The $\operatorname{sen} X 3-$ regX3 operon is required for Mtb survival during murine infection [11-13]. However, conflicting results have been reported for the virulence of strains deficient in $\operatorname{sen} X 3$ or regX3 in the lungs and spleens of BALB/c mice [13]. Unlike the case in other 2CRS, expression of $\operatorname{sen} X 3$ and $\mathrm{regX} 3$ is monocistronic as well as polycistronic [14,15], raising the possibility that each may function independently of the other under clinically relevant conditions and during host infection. In $M$. smegmatis, co-transcription of $\operatorname{sen} X 3$ and regX3 is required for the expression of 
phosphate-dependent genes and for optimal growth under inorganic phosphate $\left(\mathrm{P}_{\mathrm{i}}\right)$-limiting conditions $[16,17]$. Previously, we have shown that the $\operatorname{sen} X 3-$ regX $X$ operon is involved in the Mtb phosphate starvation response (PSR) [12], however the individual role of each gene in Mtb survival during $\mathrm{P}_{\mathrm{i}}$ depletion has not been characterized. Moreover, RegX3, when overexpressed in M. smegmatis, can be phosphorylated in the absence of SenX3 in $\mathrm{P}_{\mathrm{i}}$-rich medium [17], and the SenX3-RegX3 homolog PhoBR in $E$. coli also responds to nutrient starvation in addition to $\mathrm{P}_{\mathrm{i}}$ depletion [18]. These findings suggest that Mtb SenX3-RegX3 may have a broader role in Mtb virulence beyond the PSR and that these two factors may function independently of each other.

In order to further understand the role of each gene of the senX3-regX3 2CRS in Mtb virulence, and in particular the senX3-independent contribution of regX3, two different mutants deficient in $\operatorname{sen} X 3$ or $\operatorname{reg} X 3$ were studied under multiple conditions and their phenotypes were compared to the isogenic wild-type parent strain Mtb CDC1551, as well as their respective complemented strains. The expression of $\operatorname{sen} X 3$ and $\operatorname{reg} X 3$, as well as that of the phosphate specific transport gene pstC2, were evaluated in all the tested strains under physiologically relevant stress conditions. In addition, the growth and survival of each of these strains were assessed during axenic growth in nutrient-rich broth, $\mathrm{P}_{\mathrm{i}}$ depletion, nutrient starvation, and after aerosol infection in the lungs of $\mathrm{BALB} / \mathrm{c}$ mice. Our data support the hypothesis that RegX3 may have a SenX3-independent role in Mtb virulence.

\section{Results}

Confirmation of senX3::Tn and regX3::Tn complementation In order to confirm that phenotypes observed for $\operatorname{sen} X 3$ :: Tn and regX3::Tn were attributable to deficiency of $\operatorname{sen} X 3$ and $\operatorname{reg} X 3$, respectively, we complemented each mutant by reintroducing the native gene. Due to the complexity of the operon, which includes monocistronic and bicistronic transcription of each gene [15], each mutant was complemented with the entire $\operatorname{sen} X 3-\operatorname{reg} X 3$ operon. Successful complementation was confirmed by Southern blot using dig-labeled probes after DNA digestion of complement candidates, as well as the wild-type and mutant strains. As expected, digestion of genomic DNA with FseI and hybridization with dig-labeled $\operatorname{sen} X 3$ probe revealed fragments of $5.7-\mathrm{kb}$ and $7.7-\mathrm{kb}$ in the $\operatorname{sen} X 3:: \mathrm{Tn}$ complemented strain ( $\operatorname{sen} X 3::$ Tn Comp), a $3.7-\mathrm{kb}$ fragment in the wild-type strain, and a $5.7-\mathrm{kb}$ fragment in senX3::Tn (Figure 1B and D). SphI digestion of genomic DNA followed by binding of dig-labeled regX3 probe showed 4.6-kb and 7.5-kb fragments in the regX3::Tn complement candidate strains (regX3::Tn Comp), a 5.5-kb fragment in the wild-type strain, and a 7.5-kb fragment in regX3::Tn (Figure $1 \mathrm{C}$ and $\mathrm{E}$ ). In addition, kanamycin and hygromycin resistance cassettes were PCR-amplified from each of these complemented strains (data not shown). We have shown previously that bicistronic expression of regX3 was abolished in senX3::Tn, although monocistronic expression of the gene is preserved in this strain [15].

\section{Disruption of $\operatorname{sen} X 3$ reduces reg $X 3$ expression during phosphate depletion, but each gene is equally required for regulation of the phosphate-specific transport system} Mildly reduced expression of $\operatorname{sen} X 3$ and regX3 relative to $\operatorname{sig} A$ was observed in $\operatorname{reg} X 3:: T \mathrm{Tn}$ and $\operatorname{sen} X 3:: \mathrm{Tn}$, respectively, in Middlebrook $7 \mathrm{H} 9$ broth compared with the wild type parent strain (Figure 2A; $p>0.05$ ). Although regX3 can be expressed independently of $\operatorname{sen} X 3$ [15], disruption of the latter gene led to decreased Mtb expression of regX3 during $\mathrm{P}_{\mathrm{i}}$ depletion $(p<0.01)$ (Figure $2 \mathrm{~B}$ ). Gene expression levels of $\operatorname{sen} X 3$ and regX3 were restored in senX3::Tn Comp and regX3::Tn Comp, respectively, during $\mathrm{P}_{\mathrm{i}}$ depletion, but the cognate genes were overexpressed in each complemented strain relative to the wild type $(p<0.05)$ (Figure $2 \mathrm{~B})$, likely due to a second copy of each of these genes in the respective complemented strains. In Middlebrook 7H9 broth, mild down-regulation of pstC2 expression was observed in senX3::Tn and regX3:: Tn relative to the wild-type strain $(p<0.01)$, and wild-type pstC2 transcript levels were restored in each of the complemented strains (Figure 2C). Each mutant showed similar, significant down-regulation of the $\mathrm{P}_{\mathrm{i}}$-specific transport gene $p s t C 2$ relative to the wild-type strain during $\mathrm{P}_{\mathrm{i}}$ depletion $(p<0.01)$, and wild-type expression levels of the gene were restored in each complemented strain (Figure 2D). Disruption of $\operatorname{sen} X 3$ led to decreased expression of regX3 during nutrient starvation $(p<0.05)$. However, wild-type levels of $\operatorname{sen} X 3$ and $\operatorname{reg} X 3$ expression were not observed in senX3::Tn Comp and regX3::Tn Comp, respectively, although $\operatorname{sen} X 3$ expression was partially restored in regX3::Tn Comp under this condition (data not shown). The abundance of pstC2 transcripts was not significantly altered in either mutant relative to wild type during nutrient starvation $(p>0.05)$.

\section{sen $X 3$ and regX3 are equally required for Mtb growth during $\mathrm{P}_{\mathrm{i}}$ depletion}

The growth kinetics of each mutant and its respective complement, together with the isogenic wild-type strain, were studied during $\mathrm{P}_{\mathrm{i}}$ depletion $\left(50 \mu \mathrm{M} \mathrm{P} \mathrm{P}_{\mathrm{i}}\right)$ and in reconstituted, $\mathrm{P}_{\mathrm{i}}$-replete $7 \mathrm{H} 9$ broth $\left(25 \mathrm{mM} \mathrm{P} \mathrm{P}_{\mathrm{i}}\right)$. Each strain showed equivalent growth in $\mathrm{P}_{\mathrm{i}}$-replete $7 \mathrm{H} 9$ broth (Figure 3A), suggesting that $\operatorname{sen} X 3$ and regX3 are dispensable for axenic Mtb growth when $P_{i}$ is abundant. However, senX3::Tn and regX3::Tn showed a marked growth defect and premature entry into stationary phase relative to the isogenic wild-type and their respective complemented strains during $\mathrm{P}_{\mathrm{i}}$ depletion (Figure 3B). 


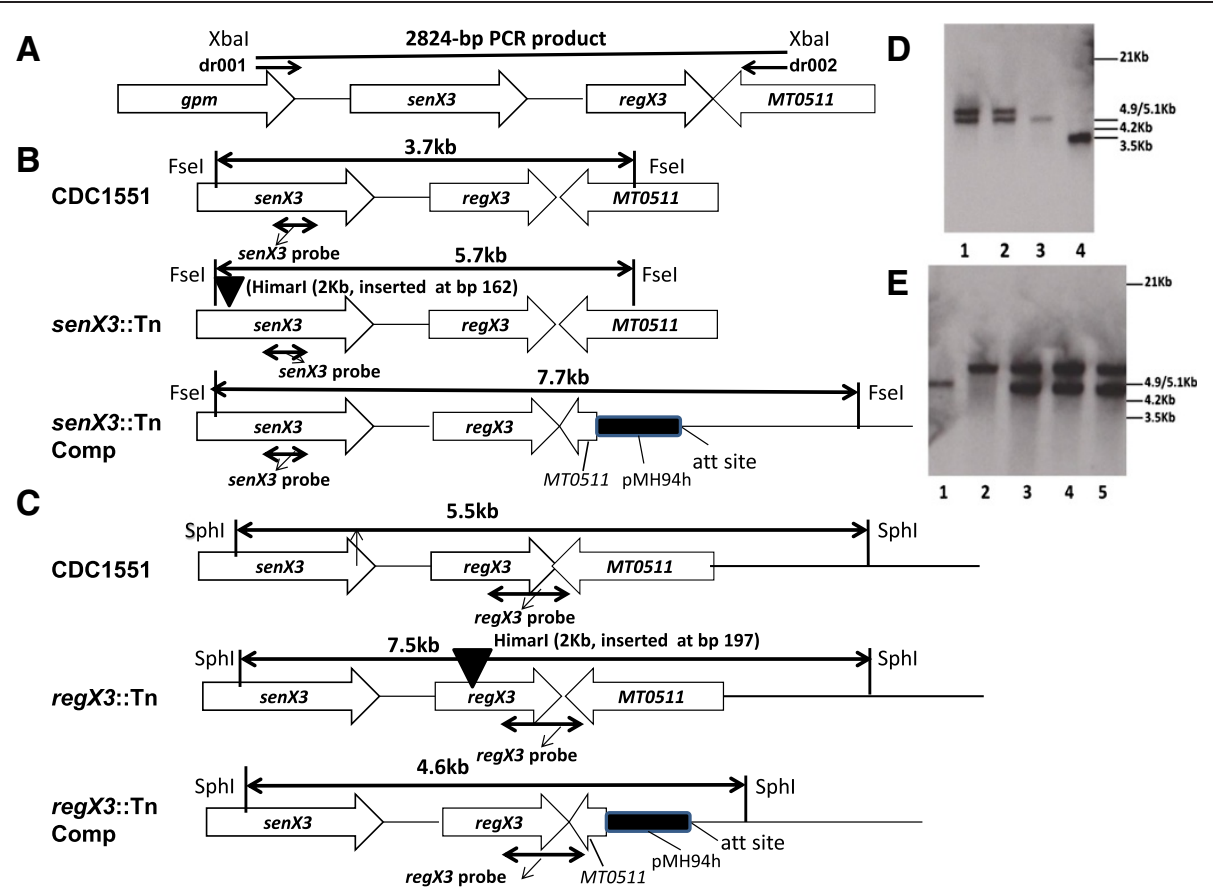

Figure 1 Genetic confirmation of complementation of senX3::Tn and regX3::Tn. (A). Diagram of a 2824-bp fragment containing the senX3-regX3 operon from the genome of wild-type CDC1551. (B) Fsel digestion of genomic DNA and hybridization with dig-labeled senX3 probe reveals fragments measuring 3.7-kb and 5.7-kb in CDC1551 and senX3::Tn, respectively, as well as 5.7-kb and 7.7-kb fragments in senX3::Tn Comp. (C) Sphl digestion of genomic DNA followed by hybridization with dig-labeled regX3 probe reveals 5.5-kb and 7.5-kb fragments in CDC1551 and regX3::Tn, respectively, as well as 7.5-kb and 4.6-kb fragments in regX3::Tn Comp. (D) Southern analysis of senX3 complementation. Lanes 1 and 2: SenX3::Tn Comp candidates with appropriately-sized bands; Lane 3: SenX3:Tn; Lane 4: Wild-type CDC1551. (E) Southern analysis of regX3 complementation. Lane 1: Wild-type CDC551; Lane 2: regX3::Tn; Lanes 3-5: regX3::Tn Comp candidates with appropriately-sized bands.

No obvious difference in growth was observed between the mutants.

Previously, we have shown that Mtb bacilli undergo elongation following $\mathrm{P}_{\mathrm{i}}$ depletion [12]. In order to determine the effect of senX3 or regX3 deficiency on Mtb morphology during $\mathrm{P}_{\mathrm{i}}$ depletion, we used transmission electron microscopy to capture images of at least 40 bacilli of each strain following 21 days of $P_{i}$ depletion or during exponential growth in reconstituted, $\mathrm{P}_{\mathrm{i}}$-replete $7 \mathrm{H} 9$ broth. We found that the mean length of $\mathrm{P}_{\mathrm{i}}$-depleted senX3::Tn and regX3::Tn bacilli was $2.62 \pm 0.72$ and $2.96 \pm 0.69$, respectively, while the mean length of isogenic wild-type bacilli was $4.02 \pm 1.10(p>0.05)$. The mean length of the $\operatorname{sen} X 3:: \mathrm{Tn}$ and $\mathrm{regX}:: \mathrm{Tn}$ complement bacilli was $4.02 \pm 1.36$ and $3.76 \pm 0.85$, respectively $(p>0.05)$ (Figure 4A-E). The mean length of $\operatorname{sen} X 3:: T n$ bacilli $(2.48 \pm 0.48)$ and $r e g X 3:: T n$ bacilli $(2.44 \pm 0.72)$ was equivalent to that of wild-type bacilli $(2.46 \pm 0.60)$ during exponential growth in $\mathrm{P}_{\mathrm{i}}$-replete $\left(25 \mathrm{mM} \mathrm{P}_{\mathrm{i}}\right)$ broth $(p>0.05)$.

\section{Higher survival of senX3::Tn relative to regX3::Tn during nutrient starvation}

Since both monocistronic and bicistronic expression of regX3 is observed in nutrient-starved Mtb [15], we next studied the requirement for each type of gene expression during nutrient starvation. After 7 days of nutrient star-

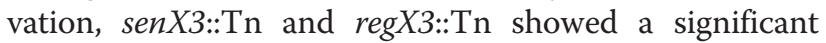
survival defect relative to wild type $(p<0.05$ and $p<0.01$, respectively), which was complemented in $r e g X 3:: \operatorname{Tn}$ Comp but not in $\operatorname{sen} X 3:: T n$ Comp (Figure 5). At this time point, $\operatorname{sen} X 3:: \mathrm{Tn}$, in which monocistronic expression of regX3 is maintained [15], showed higher survival relative to $r e g X 3:$ : $\operatorname{Tn}(p<0.01)$. By 14 days after nutrient starvation, regX3:: Tn showed markedly reduced survival relative to wild type $(p<0.01)$ and $\operatorname{sen} X 3:: \operatorname{Tn}(p<0.01)$. The survival defect at 14 days was almost completely reversed in regX3:: $\mathrm{Tn}$ Comp ( $p<0.01$ relative to the mutant).

\section{Higher survival of senX3::Tn relative to regX3::Tn during} chronic infection in mouse lungs

In order to evaluate the potential senX3-independent role of regX3 on Mtb virulence in vivo, we aerosol-infected mice with wild type, $\operatorname{sen} X 3:: \operatorname{Tn}, \operatorname{reg} X 3:: \mathrm{Tn}$, and their respective complemented strains. We observed no significant growth defect for the two mutants during the first 15 days post-infection relative to the wild-type (Figure 6). By Day 31, the wild-type strain achieved a peak bacterial CFU of $6.89 \pm 0.13 \log _{10}$ in the lungs, and a reduction in mean lung 


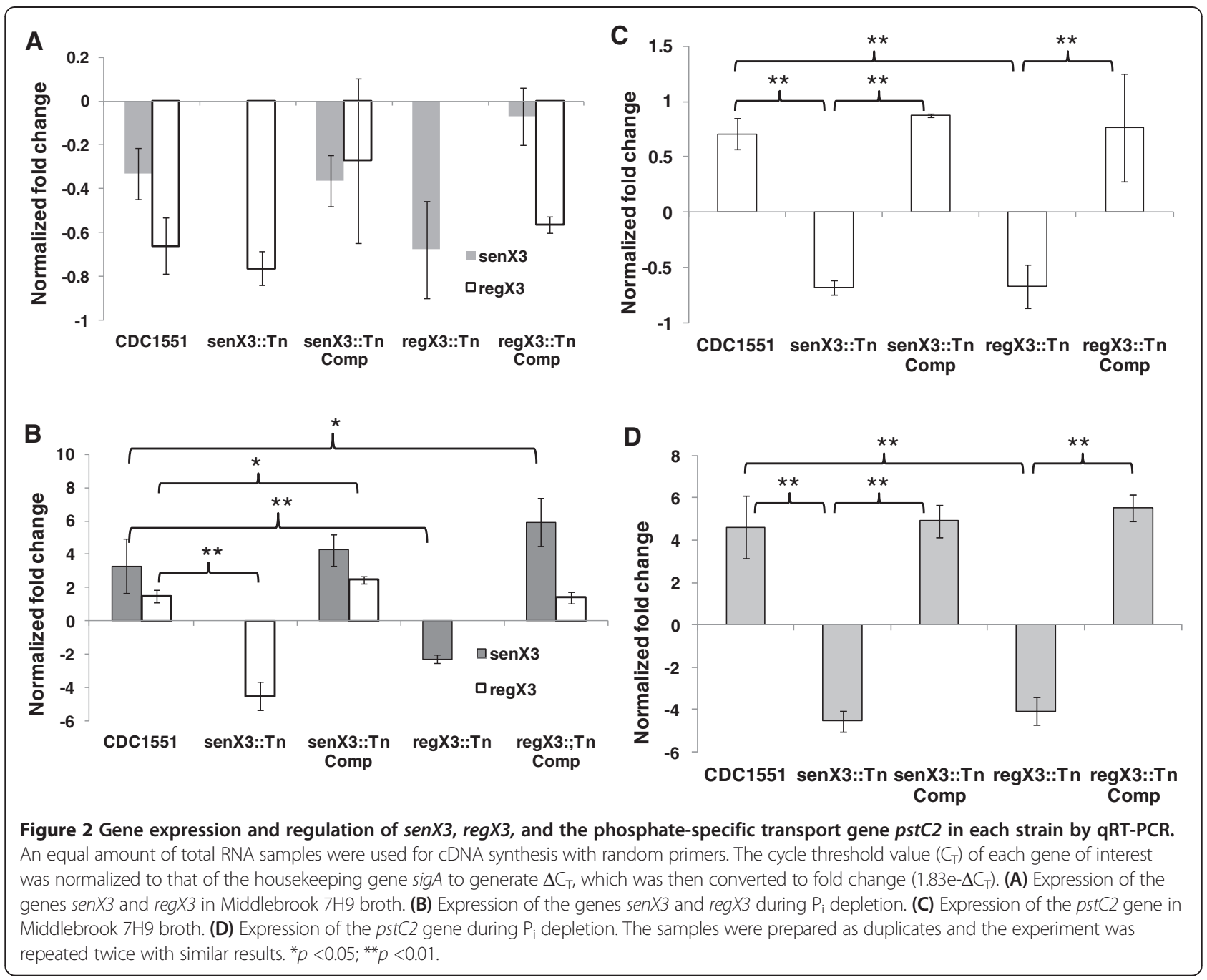

CFU of $0.5 \log _{10}(p<0.01)$ and $1.51 \log _{10}(p<0.01)$ was observed in senX3::Tn and regX3::Tn, respectively. By Day 124, mice infected with senX3::Tn and $r e g X 3::$ Tn had significant reductions in lung bacillary loads of $1.6 \log _{10} \mathrm{CFU}$ $(p<0.01)$ and $2.6 \log _{10}$ CFU $(p<0.01)$ relative to mice infected with the wild-type strain. Interestingly, as in the case of nutrient starvation, consistently and significantly higher lung bacillary burdens were observed in mice infected with senX3::Tn compared to those in mice infected with regX3:: Tn at Day $31(p<0.01)$, Day $64(p<0.01)$, and Day 124 $(p=0.05)$ post-infection (Figure 6). In fact, at Day 124, the lungs of mice infected with senX3::Tn had more than 10-fold higher mean CFU relative to those of mice infected with regX3:: $\operatorname{Tn}(p=0.05)$. This lung survival defect was partially restored in regX3::Tn Comp ( $p=0.05$

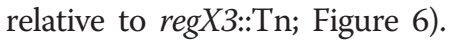

senX3 and regX3 contribute to Mtb-induced lung pathology Histopathological examination of mouse lung samples at Day 124 revealed a patchy lymphocytic bronchiolitis with varying extension of the inflammation into the adjoining airways characterized by intra-alveolar macrophages and lymphoid aggregates (Figure 7A-E and Table 1). Bronchiolar obliteration and coalescence of bronchioles was not identified. A perivascular lymphocytic infiltrate was also noted in some of the cases. Lung inflammation was less pronounced in animals infected with senX3::Tn and regX3:: Tn compared with the wild-type strain and their respective complements (Figure $7 \mathrm{~A}-\mathrm{E}$ ). One-way analysis of variance (ANOVA test) across strains showed a statistically significant difference of means in percent inflamed bronchioles $(p<0.05)$ (Table 1). However, the small number of cases examined precludes a definitive assessment of statistical significance. Acid-fast staining revealed no major differences between groups (data not shown).

\section{Discussion}

SenX3-RegX3 is among the best characterized 2CRS in Mtb $[9,10]$, yet many questions remain about its role in virulence. Homologs of $\operatorname{sen} X 3$ and $\operatorname{reg} X 3$ are found in 

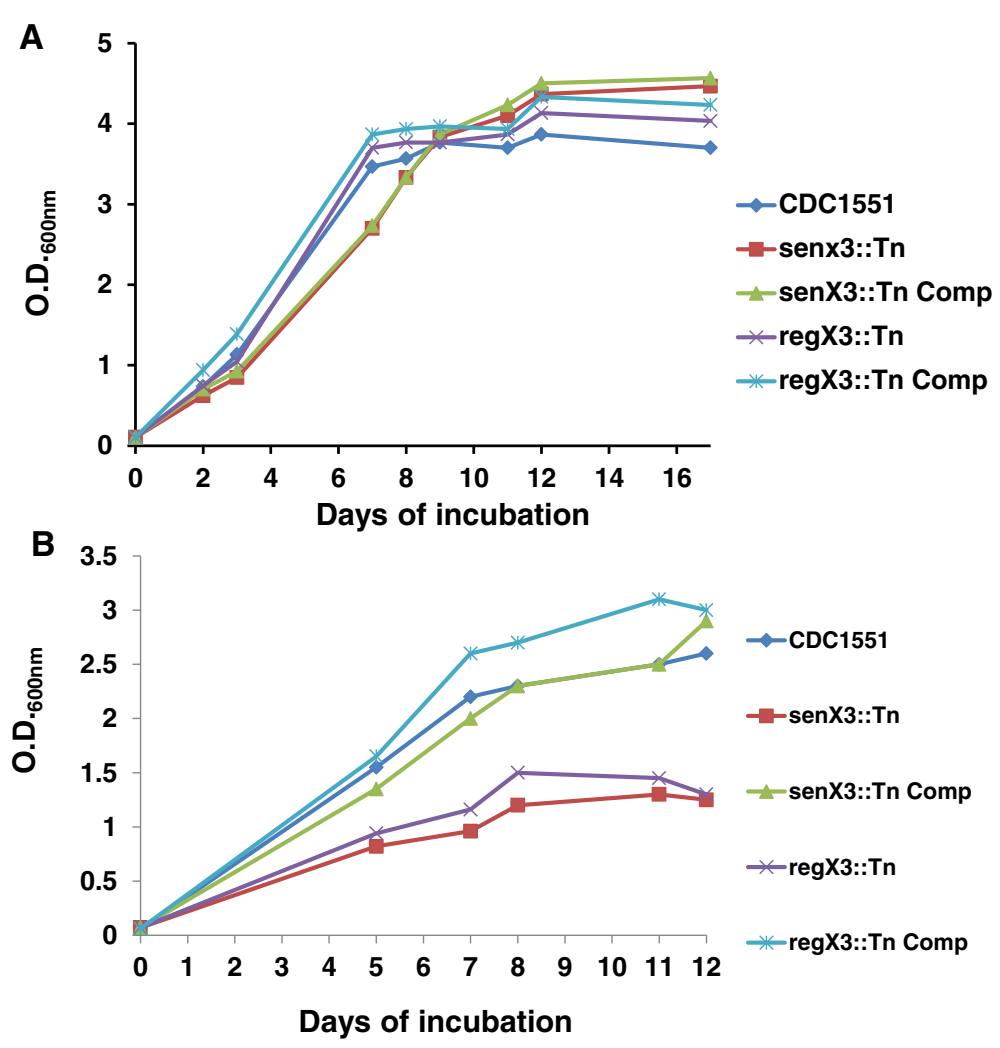

Figure 3 Mtb sen $X 3$ and regX3 are required for optimal growth during $P_{i}$ depletion, but not in $P_{i}$-replete broth. The wild-type, sen $X 3:: T n$ senX3::Tn Comp, regX3::Tn, and regX3::Tn Comp strains were each cultured in reconstituted 7 H9 broth containing $25 \mathrm{mM} \mathrm{P}_{\mathrm{i}}(\mathbf{A})$ and $\mathrm{P}_{\mathrm{i}}$-depleted broth $\left(50 \mu \mathrm{M} \mathrm{P}_{\mathrm{i}}\right) \mathbf{( B )}$. Each experiment was repeated twice with similar values of optimal density $\left(\mathrm{O} . \mathrm{D} .60 \mathrm{n}_{\mathrm{nm}}\right)$.

the genomes of various mycobacterial species, indicating that this evolutionarily conserved 2CRS may play a fundamental regulatory role in mycobacterial physiology [19]. Unlike other 2CRS, in which expression of the operon is bicistronic and auto-regulatory, $\operatorname{sen} X 3$ and $\operatorname{reg} X 3$ can be transcribed independently of each other [15]. In particular, the intergenic region between the two genes contains several mycobacterium interspersed repetitive units (MIRU), which exist only in M. leprae and members of the Mtb complex [9,14,17,20,21], and which can drive sen $X 3$-independent expression of regX3 [15]. In the current study, we sought to investigate the senX3-independent contribution of regX3 to Mtb gene regulation, growth, and survival under various physiologically relevant growth-limiting conditions in vitro and in vivo.

We found that the genes $\operatorname{sen} X 3$ and $\operatorname{regX} 3$, while dispensable for Mtb growth in nutrient-rich broth, are equally required for optimal growth and morphological response during $\mathrm{P}_{\mathrm{i}}$ depletion. In addition, as evidenced by the statistically greater survival of $\operatorname{sen} X 3:: T n$ relative

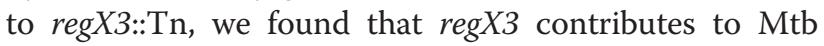
survival independent of $\operatorname{sen} X 3$ during prolonged nutrient starvation and chronic infection in mouse lungs.
Although SenX3-RegX3 has been implicated in the mycobacterial PSR $[12,16,17]$, the functional role of each gene in this operon has not been characterized previously during $\mathrm{P}_{\mathrm{i}}$ depletion. $\mathrm{P}_{\mathrm{i}}$ depletion is believed to be a physiologically relevant microenvironment encountered by $\mathrm{Mtb}$ within the arrested macrophage phagolysosome [22]. Mtb senX3-regX3 is upregulated in response to $P_{i}$ depletion and expression of the phosphate-specific transport operon pstS3-pstC2-pstA1 is RegX3-dependent [12]. Previously, we have shown monocistronic upregulation of $\operatorname{sen} X 3$ and $\operatorname{reg} X 3$ during $\mathrm{P}_{\mathrm{i}}$ depletion [15], which differs from M. smegmatis, in which the senX3-regX3 operon is co-transcribed. In the current study, we found decreased expression of regX3 in the senX3-deficient mutant relative to the wild type during $P_{i}$ depletion, which could be restored by reintroduction of $\operatorname{sen} X 3$. Decreased $r e g X 3$ expression in $\mathrm{P}_{\mathrm{i}}$-depleted $\operatorname{sen} X 3:: \mathrm{Tn}$ may be due to decreased co-transcription with $\operatorname{sen} X 3$ or down-regulation of independently expressed regX3. Although the $\operatorname{sen} X 3$ promoter is autoregulatory and activated by RegX3, which is phosphorylated by SenX3 [23], it is unknown whether the intergenic region driving independent regX3 expression is also RegX3-dependent, and, hence, SenX3-dependent. 


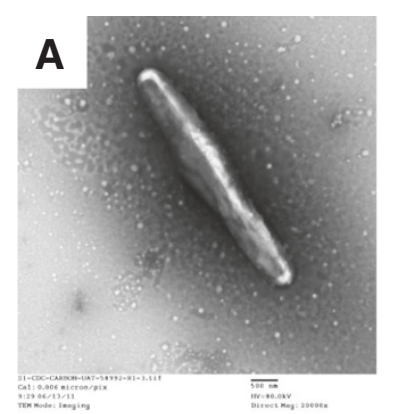

CDC1551

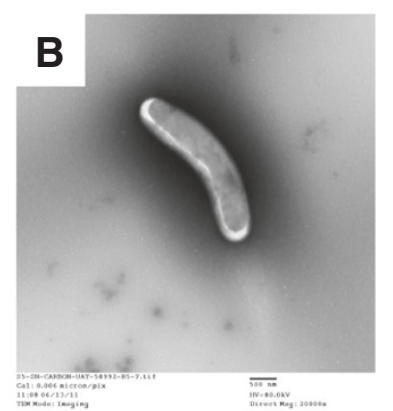

senX3::Tn

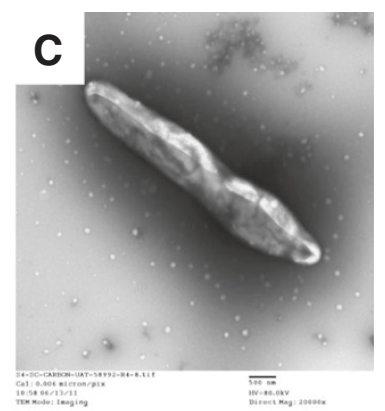

senX3:: Tn Comp

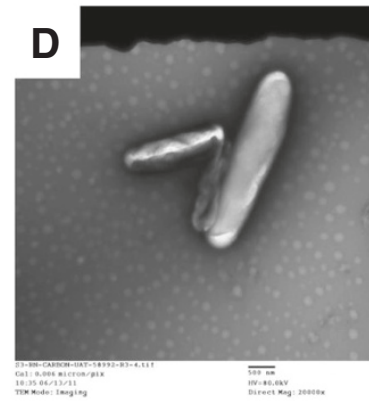

regX3::Tn

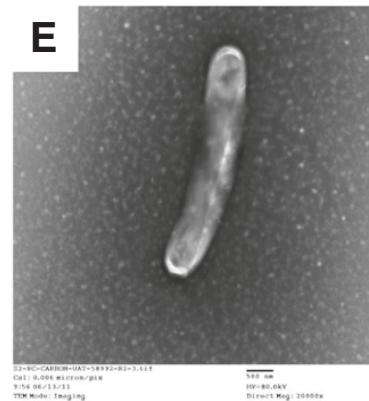

regX3 ::Tn Comp

Figure 4 The contribution of senX3 and regX3 to bacillary elongation during $P_{i}$ depletion. Transmission electron microscopy (TEM) was used to compare the morphology of all the strains after growth in reconstituted $7 \mathrm{H} 9$ broth containing $50 \mu \mathrm{M} \mathrm{P}_{\mathrm{i}}$ for 21 days. The images are representative of the following strains: A. Wild type; B. senX3::Tn; C. senX3::Tn Comp; D. regX3::Tn; E. regX3::Tn Comp (20,000x magnification).

We found that Mtb mutants deficient in $\operatorname{sen} X 3$ or regX3 exhibited similar growth defects during $\mathrm{P}_{\mathrm{i}}$ depletion. Despite expression of regX3 in the senX3-deficient mutant, it appears that RegX3 was not functional, as expression of the RegX3-dependent, $\mathrm{P}_{\mathrm{i}}$-specific transport gene pstC2 was dramatically downregulated in this strain. Our results are consistent with monocistronic, $\mathrm{P}_{\mathrm{i}}$-dependent expression of each gene and the putative role of SenX3 as a $P_{i}$ sensor [23]. Therefore, although monocistronic expression of $\operatorname{regX} 3$ is preserved in senX3::Tn [15],

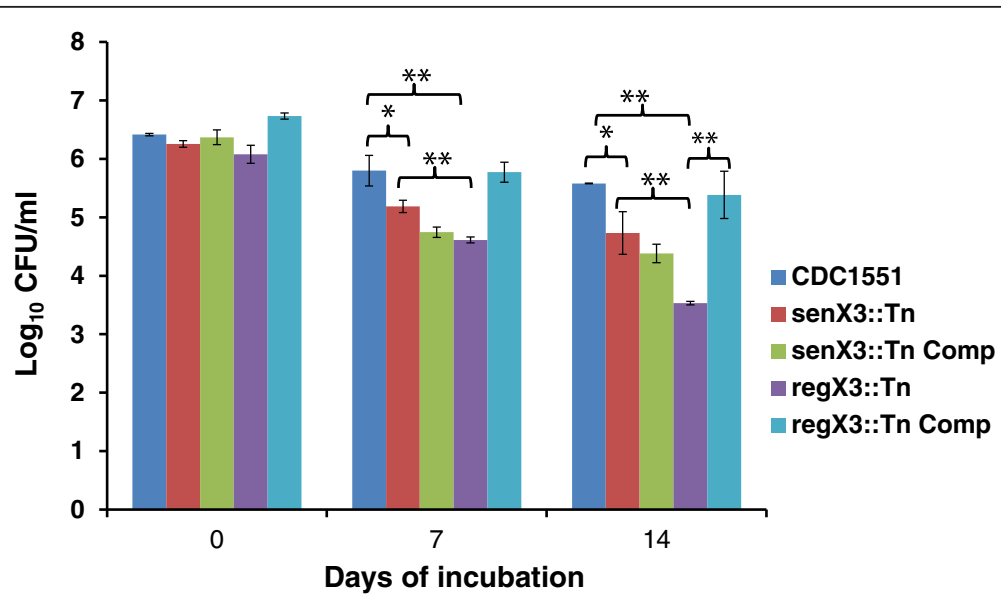

Figure 5 Both sen $X 3$ and regX3 are required for Mtb survival during nutrient starvation, although there appears to be a senX3-independent contribution of regX3. The wild-type CDC1551, senX3::Tn, senX3::Tn Comp, regX3::Tn, and regX3::Tn Comp were subcultured in 1XPBS with 0.05\% Tween- 80 and CFU were counted at different time points after plating the diluted cultures on Middlebrook $7 \mathrm{H} 10$ plates (mean \pm SD) and incubating for 21 days. Triplicate samples were used in the experiment and the experiment was repeated twice under the same condition. ${ }^{*} p<0.05 ;{ }^{* *} p<0.01$. 


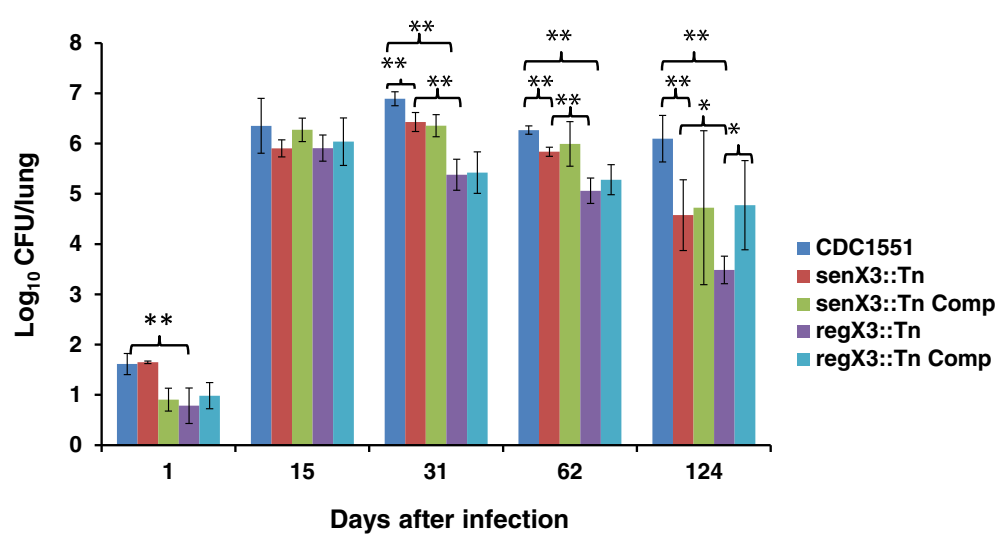

Figure 6 Both senX3::Tn and regX3::Tn are attenuated, but there appears to be a senX3-independent contribution of regX3 for long-term Mtb survival in mouse lungs. Separate groups of BalB/c mice (4-5 mice per group) were aerosol-infected with the wild-type CDC1551, senX3::Tn, senX3::Tn Comp, regX3::Tn, and regX3::Tn Comp. ${ }^{*} p<0.05 ;{ }^{* *} p<0.01$.

the cognate HK SenX3 may be required to phosphorylate and activate RegX3 during $\mathrm{P}_{\mathrm{i}}$ depletion, thereby triggering the PSR. In vitro studies in many bacteria have provided evidence in favor of the specificity of 2CRS, in which the HK show a remarkable kinetic preference for their cognate RR primarily at the level of molecular reorganization [24-31]. For example, in B. subtilis the HK KinA can phosphorylate either SpoOF or Spo0A, but with more than 50,000-fold preference for Spo0F during sporulation $[24,25]$.
Interestingly, despite similar growth phenotypes of senX3::Tn and regX3::Tn during $\mathrm{P}_{\mathrm{i}}$ limitation, the $\operatorname{sen} X 3-$ deficient mutant showed markedly higher survival relative to the regX3-deficient mutant upon prolonged nutrient starvation and in the lungs of mice, while both mutants were attenuated compared with the wild-type. Our gene expression results demonstrate reduced but detectable expression of regX3 in the senX3-deficient mutant. This discordance in phenotypes suggests the possibility that independently transcribed regX3 may be translated and

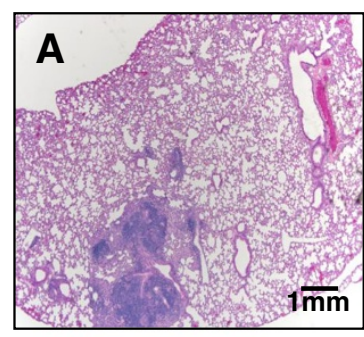

CDC1551

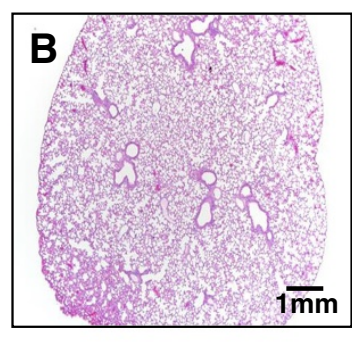

$\operatorname{sen} X 3:: T n$
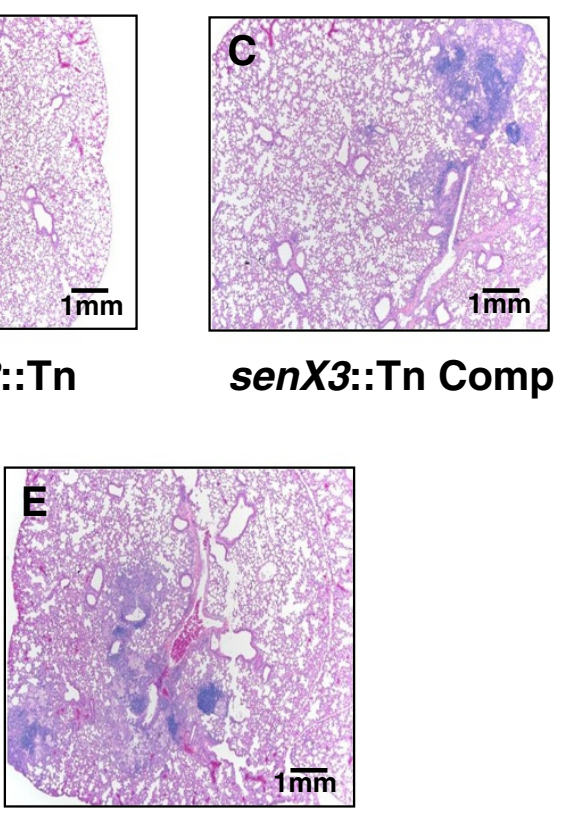

regX3::Tn Comp

Figure 7 Histological evaluation of infected mouse lungs at Day 124 post-infection. Hematoxylin-eosin stains, 200x magnification. A. CDC1551; B. senX3::Tn mutant; C. senX3::Tn Comp; D. regX3::Tn; E. regX3::Tn Comp. 
Table 1 Histological examination of Mtb-infected mouse lungs

\begin{tabular}{|c|c|c|c|c|c|c|c|}
\hline Strain & $\begin{array}{l}\text { Peribronchiolar } \\
\text { inflammation }\end{array}$ & $\begin{array}{l}\text { Degree of } \\
\text { inflammation }\end{array}$ & $\begin{array}{l}\text { Extension of inflammation } \\
\text { into airway }\end{array}$ & $\begin{array}{l}\text { Lymphoid } \\
\text { aggregates }\end{array}$ & $\begin{array}{l}\text { Bronchioles } \\
\text { inflamed }\end{array}$ & $\begin{array}{l}\text { No. of bronchioles } \\
\text { per slide }\end{array}$ & $\begin{array}{l}\% \text { of inflamed } \\
\text { bronchioles }\end{array}$ \\
\hline CDC1551 & yes & mild to mod & no & yes & 3.75 & 37.25 & 10 \\
\hline $\operatorname{sen} \times 3:: \mathrm{Tn}$ & no & none & no & $\mathrm{n} / \mathrm{a}$ & 0.25 & 45 & 1 \\
\hline senX3::Tn Comp & yes & mild to mod & yes & yes & 6.75 & 40.75 & 17 \\
\hline regX3:: Tn & no & none & no & $\mathrm{n} / \mathrm{a}$ & 3.25 & 36.75 & 9 \\
\hline regX3::Tn Comp & yes & mild & yes & yes & 7.6 & 40.2 & 19 \\
\hline
\end{tabular}

phosphorylated in the absence of SenX3, thereby initiating transcription of the RegX3 regulon $[15,17,23]$. In $M$. smegmatis, the essential gene regX3 can be activated in the absence of the nonessential gene $\operatorname{sen} X 3$ in $\mathrm{P}_{\mathrm{i}}$-replete broth, suggesting the existence of alternative mechanisms of RegX3 phosphorylation [17]. Similarly, in E. coli the RegX3 homologue PhoB can be phosphorylated by the $\mathrm{HK}$ EnvZ [32], CreC (PhoM), or acetyl phosphate in the absence of $\mathrm{PhoR}$ in $\mathrm{P}_{\mathrm{i}}$-independent pathways [33]. Precedents for phosphorylation of RR by noncognate HK are also present in Mtb. Thus, the Mtb dormancy response regulator DosR can be phosphorylated by its cognate HK DosS or by the orphan HK DosT [34,35]. Although 2CRS usually maintain specificity to prevent unwanted cross-talk [24-31], significant sequence and structure similarity in HK and RR, as well as the existence of small molecule phosphodonor acetylphosphate make cross-regulation possible [36-38]. In addition, cross-regulation could occur at the transcriptional level $[39,40]$. Under certain circumstances many bacteria appear to employ cross-regulation in order to integrate multiple signals or diversify the response to a single input $[4,41]$. Therefore, based on our initial findings, we speculate that although Mtb senX3-regX3 2CRS maintains specificity during $P_{i}$ depletion, cross-regulation of RegX3 may facilitate a rapid response of Mtb to a changing environment in vitro and in vivo under other stresses, in which the identity of alternative HK and/or other activating factors remains to be determined. Alternatively, independently transcribed $\operatorname{Reg} X 3$ may be functional in the absence of phosphorylation. For example, the Pseudomonas aeruginosa RR AlgB and AlgR do not require phosphorylation by the cognate HK KinB for alginate production in vivo, indicating that these RR may mediate activation of gene expression through alternative mechanisms [5]. We speculate that the SenX3-RegX3 2CRS may provide a common means by which to transduce the signals of $\mathrm{P}_{\mathrm{i}}$ depletion and nutrient starvation, leading to induction of the stringent response, which is critical for Mtb persistence in the host $[42,43]$. Our findings are consistent with the function of the homologous PhoBR 2CRS in E. coli, which regulates the transcriptional response to $\mathrm{P}_{\mathrm{i}}$ depletion and nutrient starvation $[18,44]$. The mechanism of regX3 regulation during nutrient starvation and in vivo infection remains to be identified.

Higher survival of $\operatorname{sen} X 3:: T n$ relative to $\operatorname{reg} X 3$ ::Tn during chronic infection in mice is consistent with previous data showing higher survival of a sen $X 3$ deletion mutant relative to a regX3 deletion mutant in mouse spleens [13]. However, our data conflict with those of Rickman et al. in that they showed greater attenuation of the $\operatorname{sen} X 3$ deletion strain in mouse lungs relative to the regX3 deletion strain. These discrepant findings may be due to methodological differences between our study and that by Rickman et al. The latter study used H37Rv, in which the sen $X 3-r e g X 3$ IR comprises three identical 77-bp MIRU rather than two 77-bp MIRU and one 53-bp MIRU, as in the CDC1551 strain used in our study $[13,14]$. In addition, Rickman et al. used intravenous infection rather than aerosol infection, although both studies used BALB/c mice. Nevertheless, these two studies corroborate our recent finding that $\operatorname{sen} \mathrm{X} 3$ and $\operatorname{reg} \mathrm{X} 3$ do not simply function as a bicistronic operon, as previously thought [14], since, in such a case, disruption of senX3 would be expected to yield mutant phenotypes identical to those of a regX3-deficient strain. In the current study, both complemented strains restored wildtype growth and survival during $\mathrm{P}_{\mathrm{i}}$ depletion, and, in the case of regX3::Tn Comp, during nutrient starvation and in the lungs of mice. However, unlike in a previous study [13], our complemented strains failed to restore the wildtype phenotype during mouse infection. There are several potential explanations for these discrepant findings. In comparison to the cloning strategy by Rickman et al., our senX3-regX3 complementation construct lacked a 211-bp sequence upstream of the $\operatorname{sen} X 3$ gene, which may have altered regulation of this gene during the in vitro stress conditions studied and mouse infection. Another difference between the two complementation approaches is that in the earlier study the $\operatorname{sen} X 3$ and $\operatorname{reg} X 3$ genes were fused together by deleting the intergenic region [13]. On the other hand, each of our complemented strains included this intergenic region, since we recently described the potential importance of its promoter activity in driving sen $X 3$-independent expression of $\operatorname{reg} X 3$ [15]. The 
precise role of this intergenic region in regulating expression of each of these genes requires further study. In addition, the presence of a second copy of the regX3 gene may have had a deleterious effect on in vitro and in vivo survival. As in the case of other defective complemented strains, the chromosomal location at the recombination site may have affected proper expression of $\operatorname{sen} X 3$ and regX3. Alternatively, the development of other occult mutations during genetic construction of these strains may have contributed to their reduced virulence relative to the wild-type strain. However, deficiency of $\operatorname{sen} X 3$ or regX3 was reported previously to be associated with reduced Mtb virulence in mice, and the attenuated mutant phenotypes were fully complemented in the study by Rickman et al. [13]. Therefore, we favor the explanation that our complementation strategy, as described above, contributed to the incomplete restoration of the wildtype phenotypes in the complemented strains. The mechanisms by which $\operatorname{sen} X 3$ and $\operatorname{reg} X 3$ are regulated under different stress conditions require further characterization.

\section{Conclusion}

Our data raise the interesting possibility that differential regulation of $\operatorname{sen} X 3$ and $\operatorname{reg} X 3$ may have evolved to allow for simultaneous coordination of the Mtb PSR [12], while providing a common means by which bacilli may respond to a variety of different physiologically relevant stress conditions. In particular, the mechanisms underlying the SenX3-independent contribution of RegX3 to Mtb virulence deserves further investigation.

\section{Methods}

\section{Growth conditions and bacterial strains}

Supplemented Middlebrook 7H9 broth (7H9 broth, Difco), reconstituted $7 \mathrm{H} 9$ broth containing $50 \mu \mathrm{M} \mathrm{P}_{\mathrm{i}}$ ( $\mathrm{P}_{\mathrm{i}}$ depletion) [12], and 1xPBS (Biological Quality) containing 0.05\% Tween-80 (nutrient starvation) [45] were used to study growth kinetics and bacterial survival. Mycobacterium tuberculosis CDC1551 [46] was used as the wild-type strain in all experiments. Mtb strains deficient in Rv0490/ MT0509/senX3 (senX3::Tn; Tn insertion at bp 162/1233) and Rv0491/MT0510/regX3 (regX3::Tn; Tn insertion at bp $197 / 693$ ) were generated previously by mutagenesis of Mtb CDC1551 with the Himar1 transposon (Tn) [47]. The Tn insertion in the senX3::Tn mutant is expected to abrogate histidine kinase function, since the phospho-acceptor domain is located between bp 465-657. Similarly, disruption of regX3 phospho-receiver and DNA-binding domains at bp 21-345 and bp 459-684, respectively, is expected by the Tn insertion in the regX3::Tn mutant.

\section{Complementation of senX3::Tn and regX3::Tn mutant strains}

The E. coli-mycobacterium shuttle vector pMH94 [48] was used for complementation of $\operatorname{sen} X 3:: T$ n and regX3::Tn. A 2,824-bp DNA fragment containing the entire senX3-regX3 coding region, including 324-bp of 5 ' flanking sequence and 378-bp of 3' flanking sequence was PCR-amplified from Mtb CDC1551 genomic DNA using primers dr001 and dr002 (Table 2 and Figure 1A), which introduced an $\mathrm{XbaI}$ site at the 5 ' end of each PCR product. After digestion with XbaI, the 2,824-bp PCR product was ligated with similarly digested pMH94, yielding psenX3-regX3, which was transferred into $E$. coli $\mathrm{DH} 5 \alpha$ competent cells, followed by plating on hygromycin-containing LB agar plates. After confirmation by DNA sequencing, the construct was electroporated separately into $\operatorname{sen} X 3:: T n$ and regX3::Tn competent Mtb cells. Individual transformant colonies were selected on $7 \mathrm{H} 10$ agar plates containing kanamycin $(25 \mu \mathrm{g} / \mathrm{ml})$ and hygromycin $(50 \mu \mathrm{g} / \mathrm{ml})$.

Genomic DNA was purified from senX3::Tn and regX3::Tn complemented strain candidates. Genetic com-

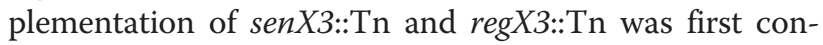
firmed by PCR. Specifically, the kanamycin gene from each transposon insertion was PCR-amplified using the primer pair kan-F/kan-R and the hygromycin gene from the shuttle vector was amplified using hyg4-F/hyg4-R. The sequences of each primer pair are listed in Table 2. In order to further confirm complementation of $\operatorname{senX3::}$ Tn and regX3::Tn, Southern blotting was performed using DIG High Prime DNA Labeling and Detection Starter Kit I according to the manufacturer's protocol (Roche). Genomic DNA from senX3::Tn and regX3::Tn complement candidates was digested with FseI and SphIHF (New England Biolabs), respectively, and electrophoresis was performed on $1 \%$ agarose gels. Following denaturation and neutralization, the gels were transferred onto positively charged nylon membranes (GE Healthcare). DNA fragments containing the $\operatorname{sen} X 3$ and

Table 2 List of primers used in this study

\begin{tabular}{lll}
\hline Primer & Sequence $\left(\mathbf{5}^{\prime} \mathbf{-} \mathbf{3}^{\prime} \mathbf{)}\right.$ & Purpose of amplification \\
\hline dr001-F & CCCTCTAGAACGAATCGTCGGACTGAC & $\begin{array}{l}\text { senX3-regX3 operon } \\
\text { and flanking sequence }\end{array}$ \\
dr002-R & CCCTCTAGAAGGGAGATCGCCAAGCTAC & senX3 probe and \\
senX3-F & CCGAGTTGATCGAGCTATCC & gene expression \\
senX3-R & AGTGCGGTAACCAGCAGAGT & regX3 probe \\
dl15-F & GCTGACGACTACGTGACCAA & \\
dl16-R & CGACGAGCAGCTTGTCC & kanamycin gene \\
kan-F & CTGTGCTCGACGTTGCACT & \\
kan-R & AGCCAACGCTATGTCCTGAT & hygromycin gene \\
hyg4-F & AGGTCTTCCCGGAACTGCTG & \\
hyg4-R & TCCTCGAACACCTCGAAGTC & gene expression \\
regX3-F & TGTTGATTGTGGAGGACGAG & \\
regX3-R & CGCAACTGCTTGCATACATC & \\
pstC2-F & GTCGATCATCTTCGGGTGT & gene expression \\
pstC2-R & ATITGGATCAGCGGAGTCTG & \\
\hline
\end{tabular}


regX3 genes on the membranes were detected by using digoxigenin(dig)-labeled $\operatorname{sen} X 3$ and regX3 probes, respectively, which were generated by adding dig-dUTP in PCR reactions containing primer pairs senX3-F and senX3-R (yielding a 196-bp fragment of the $\operatorname{sen} X 3$ gene) or primer pairs dl15 and dl16 (yielding a 576-bp fragment of the regX3 gene) (Table 2). After pre-hybridization, the membranes were hybridized with dig-labeled $\operatorname{sen} X 3$ or regX3 probes at $68^{\circ} \mathrm{C}$ overnight, prior to addition of anti-digoxigenin-AP. After stringent washes, the membranes were incubated with the chemiluminescence substrate CSPD (Roche) and exposed on X-ray film at room temperature. Finally, the films were developed in a dark room (AFP imaging).

\section{Gene expression by quantitative RT-PCR (qRT-PCR)}

Total RNA from each Mtb strain was purified from nutrient- and $\mathrm{P}_{\mathrm{i}}$-starved cultures after $24 \mathrm{hr}$ followed by DNase treatment to remove contaminating DNA $[49,50]$. Gene expression levels were detected using the primer pairs listed in Table 2 and iCycler 5.0 (Bio-Rad). cDNA was synthesized with random hexamers (Invitrogen) using an equal amount of total RNA samples, which was subjected to two technical replicates of PCR amplification and then averaged to generate a single value for each biological replicate. The cycle threshold value $\left(C_{T}\right)$ measured for each gene was normalized to that of the housekeeping gene sigA under each condition and then converted to fold change $\left(1.83 \mathrm{e}-\Delta \mathrm{C}_{\mathrm{T}}\right)$ [15,51]. senX3 expression was determined by primer pair $\operatorname{sen} X 3-\mathrm{F} / \operatorname{sen} X 3-\mathrm{R}$, which amplified from bp 635 to bp 830 of the $\operatorname{sen} X 3$ gene, distal to the transposon insertion site (bp 162). regX3 expression was studied using primer pair regX3-F/regX3-R, which amplified from bp 20 to bp 212, across the transposon insertion site of the regX3 gene (bp 197). The samples were prepared as duplicates and statistical analysis was performed using two biological replicates for each sample.

\section{Growth kinetics and survival during in vitro growth conditions}

For kinetics studies during inorganic $\mathrm{P}_{\mathrm{i}}$ depletion, the pellet of each strain was washed with reconstituted Middlebrook $7 \mathrm{H} 9$ broth containing $50 \mu \mathrm{M} \mathrm{P}_{\mathrm{i}}$, resuspended in $10 \mathrm{ml}$ (final O.D.600nm $\sim 0.05$ ) of the same broth in conical tubes, and incubated at $37^{\circ} \mathrm{C}$ in a roller incubator. O.D.600nm values for each strain were measured by portable spectrometer (Biorad) at each time point up to 12 days. The growth kinetic of each strain in Middlebrook 7H9 broth (Difco) was observed up to 17 days. The experiment was repeated twice under the same growth conditions.

For nutrient starvation conditions, the bacterial pellet of each strain was washed with 1 xPBS (0.05\%Tween-80) three times followed by re-suspension in $3 \mathrm{ml}$ (final O.D.600nm $\sim 0.1$ ) of 1 xPBS (0.05\%Tween-80) in a $15-\mathrm{ml}$ conical tube prior to standing incubation at $37^{\circ} \mathrm{C}$. Colonyforming unit (CFU) counts were assessed at Day 1, Day 7, and Day 14 by plating the culture on Middlebrook $7 \mathrm{H} 10$ agar after serial dilutions (Fisher). All the samples were prepared as triplicates and the experiment was repeated twice.

\section{Transmission electron microscopy (TEM)}

Fixed phosphotungstate (PTA) negative stain for electron microscopy study was used to evaluate bacterial morphology [12]. Bacterial cultures were fixed and viewed (Hitachi H-7600 TEM [80 kV]), followed by digital capture (direct magnification, $\times 20,000$ ). The length of each strain was measured using Image J software.

\section{Animal infections}

All animal procedures followed protocols approved by the JHU Animal Care and Use Committee. Female BALB/c mice (4-6 weeks; Charles River) were housed in a Biosafety Level-3, specific pathogen-free facility and fed water and chow ad libitum. Separate groups of mice were aerosolinfected using the Inhalation Exposure System (Glas-Col, Terre Haute, IN) calibrated to deliver $\sim 10^{2}$ bacilli of one of the following Mtb strains: CDC1551, senX3::Tn, regX3::Tn, senX3::Tn complement, or regX3::Tn complement. Groups of 4 mice in each group were sacrificed on Days 1, 15, 31, 62 , and 124 post-infection. Lungs were removed aseptically and homogenized, and organ homogenates were diluted and plated on supplemented Middlebrook $7 \mathrm{H} 11$ plates to determine CFU counts (Fisher).

The upper lobe of the left lung was processed for histological evaluation [52]. Lung sections were examined for the presence or absence of bronchiolitis, bronchiolar obliteration, granulomatous inflammation, and coalescence or confluence of inflamed bronchioles. The type and predominance of inflammatory cell type (lymphocyte, macrophage, or neutrophil) was noted. For each slide both the total number of bronchioles and the number of inflamed bronchioles were counted. Sections were also examined for the presence or absence of perivascular inflammation.

\section{Statistical analysis}

Means and standard deviations were calculated for each data set. Differences between calculated means were compared by the Student's $t$ test in all experiments except for histology studies, where the difference of means in percent inflamed bronchioles was compared by ANOVA test. A p-value $\leq 0.05$ was considered statistically significant.

\section{Abbreviations}

Mtb: Mycobacterium tuberculosis; 2CRS: Two component regulatory system; HK: Histidine kinase; RR: Response regulator; $P_{\mathrm{i}}$ : Phosphate; PSR: Phosphate starvation response; ANOVA: One-way analysis of variance; MIRU: Mycobacterial interspersed repetitive unit; $C_{T}$ : Cycle threshold value; CFU: Colony-forming unit; PTA: Phosphotungstate; TEM: Transmission electron microscopy; Dig: Digoxigenin; qRT-PCR: Quantitative reverse transcriptase PCR. 


\section{Competing interests}

The authors declare that they have no competing interests.

\section{Authors' contributions}

The experimental design was developed by DR and PCK. The experiments were performed by DR. DB was responsible for histological analysis. All authors contributed to writing of the manuscript. All authors read and approved the final manuscript.

\section{Acknowledgements}

This work was supported by NIH grants Al083125 and HL106786.

\section{Author details}

${ }^{1}$ Department of Medicine, Johns Hopkins University School of Medicine, Center for Tuberculosis Research, 1551 East Jefferson Street, Room 110, Baltimore, MD 21287, USA. ²Department of Pathology, Johns Hopkins University School of Medicine, Baltimore, MD 21287, USA. ${ }^{3}$ Department of International Health, Johns Hopkins Bloomberg School of Public Health, Baltimore, MD 21205, USA.

Received: 10 July 2014 Accepted: 9 October 2014

Published online: 25 October 2014

\section{References}

1. Converse PJ, Karakousis PC, Klinkenberg LG, Kesavan AK, Ly LH, Allen SS, Grosset JH, Jain SK, Lamichhane G, Manabe YC, McMurray DN, Nuermberger $E L$, Bishai WR: Role of the dosR-dosS two-component regulatory system in mycobacterium tuberculosis virulence in three animal models. Infect Immun 2009, 77(3):1230-1237.

2. Bagchi, Mayuri G, Das TK, Tyagi JS: Molecular analysis of the dormancy response in Mycobacterium smegmatis: expression analysis of genes encoding the DevR-DevS two-component system, Rv3134c and chaperone alpha-crystallin homologues. FEMS Microbiol Lett 2002, 211(2):231-237.

3. He H, Hovey R, Kane J, Singh V, Zahrt TC: MprAB is a stress-responsive two-component system that directly regulates expression of sigma factors SigB and SigE in Mycobacterium tuberculosis. J Bacterio/ 2006, 188(6):2134-2143.

4. Laub MT, Goulian M: Specificity in two-component signal transduction pathways. Annu Rev Genet 2007, 41:121-145.

5. Ma S, Selvaraj U, Ohman DE, Quarless R, Hassett DJ, Wozniak DJ: Phosphorylation-independent activity of the response regulators AlgB and AlgR in promoting alginate biosynthesis in mucoid Pseudomonas aeruginosa. J Bacteriol 1998, 180(4):956-968.

6. Baldus JM, Green BD, Youngman P, Moran CP Jr: Phosphorylation of Bacillus subtilis transcription factor Spo0A stimulates transcription from the spollG promoter by enhancing binding to weak OA boxes. J Bacteriol 1994, 176(2):296-306.

7. Boyd JM, Lory S: Dual function of PilS during transcriptional activation of the Pseudomonas aeruginosa pilin subunit gene. J Bacterio/ 1996, 178(3):831-839.

8. Dubnau D, Hahn J, Roggiani M, Piazza F, Weinrauch Y: Two-component regulators and genetic competence in Bacillus subtilis. Res Microbio/ 1994, 145(5-6):403-411.

9. Wren BW, Colby SM, Cubberley RR, Pallen MJ: Degenerate PCR primers for the amplification of fragments from genes encoding response regulators from a range of pathogenic bacteria. FEMS Microbiol Lett 1992, 78(2-3):287-291.

10. Bretl DJ, Demetriadou C, Zahrt TC: Adaptation to environmental stimuli within the host: two-component signal transduction systems of Mycobacterium tuberculosis. Microbiol Mol Biol Rev 2011, 75(4):566-582.

11. Parish T, Smith DA, Roberts G, Betts J, Stoker NG: The senX3-regX3 two-component regulatory system of Mycobacterium tuberculosis is required for virulence. Microbiology 2003, 149(Pt 6):1423-1435.

12. Rifat D, Bishai WR, Karakousis PC: Phosphate depletion: a novel trigger for Mycobacterium tuberculosis persistence. J Infect Dis 2009, 200(7):1126-1135.

13. Rickman L, Saldanha JW, Hunt DM, Hoar DN, Colston MJ, Millar JB, Buxton RS: A two-component signal transduction system with a PAS domain-containing sensor is required for virulence of Mycobacterium tuberculosis in mice. Biochem Biophys Res Commun 2004, 314(1):259-267.
14. Supply P, Magdalena J, Himpens S, Locht C: Identification of novel intergenic repetitive units in a mycobacterial two-component system operon. Mol Microbiol 1997, 26(5):991-1003.

15. Rifat D, Karakousis PC: Differential regulation of the two-component regulatory system senX3-regX3 in Mycobacterium tuberculosis. Microbiology 2014.

16. James JN, Hasan ZU, loerger TR, Brown AC, Personne Y, Carroll P, Ikeh M, Tilston-Lunel NL, Palavecino C, Sacchettini JC, Parish T: Deletion of SenX3RegX3, a key two-component regulatory system of Mycobacterium smegmatis, results in growth defects under phosphate-limiting conditions. Microbiology 2012, 158(Pt 11):2724-2731.

17. Glover RT, Kriakov J, Garforth SJ, Baughn AD, Jacobs WR Jr: The two-component regulatory system senX3-regX3 regulates phosphate-dependent gene expression in Mycobacterium smegmatis. J Bacteriol 2007, 189(15):5495-5503.

18. Rao NN, Liu S, Kornberg A: Inorganic polyphosphate in Escherichia coli: the phosphate regulon and the stringent response. J Bacterio/ 1998, 180(8):2186-2193.

19. Cole ST, Supply P, Honore N: Repetitive sequences in Mycobacterium leprae and their impact on genome plasticity. Lepr Rev 2001, 72(4):449-461.

20. Magdalena J, Vachee A, Supply P, Locht C: Identification of a new DNA region specific for members of Mycobacterium tuberculosis complex. J Clin Microbiol 1998, 36(4):937-943.

21. Magdalena J, Supply P, Locht C: Specific differentiation between Mycobacterium bovis BCG and virulent strains of the Mycobacterium tuberculosis complex. J Clin Microbiol 1998, 36(9):2471-2476.

22. Rengarajan J, Bloom BR, Rubin EJ: Genome-wide requirements for Mycobacterium tuberculosis adaptation and survival in macrophages. Proc Natl Acad Sci U S A 2005, 102(23):8327-8332.

23. Himpens $S$, Locht C, Supply P: Molecular characterization of the mycobacterial SenX3-RegX3 two-component system: evidence for autoregulation. Microbiology 2000, 146(Pt 12):3091-3098.

24. Burbulys D, Trach KA, Hoch JA: Initiation of sporulation in B subtilis is controlled by a multicomponent phosphorelay. Cell 1991, 64(3):545-552.

25. Grimshaw CE, Huang S, Hanstein CG, Strauch MA, Burbulys D, Wang L, Hoch JA, Whiteley JM: Synergistic kinetic interactions between components of the phosphorelay controlling sporulation in Bacillus subtilis. Biochemistry 1998, 37(5):1365-1375.

26. Janiak-Spens F, Cook PF, West AH: Kinetic analysis of YPD1-dependent phosphotransfer reactions in the yeast osmoregulatory phosphorelay system. Biochemistry 2005, 44(1):377-386.

27. Igo MM, Ninfa AJ, Stock JB, Silhavy TJ: Phosphorylation and dephosphorylation of a bacterial transcriptional activator by a transmembrane receptor. Genes Dev 1989, 3(11):1725-1734.

28. Fisher SL, Jiang W, Wanner BL, Walsh CT: Cross-talk between the histidine protein kinase VanS and the response regulator PhoB: characterization and identification of a VanS domain that inhibits activation of PhoB. J Biol Chem 1995, 270(39):23143-23149.

29. Utsumi R, Brissette RE, Rampersaud A, Forst SA, Oosawa K, Inouye M: Activation of bacterial porin gene expression by a chimeric signal transducer in response to aspartate. Science 1989, 245(4923):1246-1249.

30. Tomomori C, Tanaka T, Dutta R, Park H, Saha SK, Zhu Y, Ishima R, Liu D, Tong Kl, Kurokawa H, Qian H, Inouye M, Ikura M: Solution structure of the homodimeric core domain of Escherichia coli histidine kinase EnvZ. Nat Struct Biol 1999, 6(8):729-734.

31. Tzeng $Y L$, Hoch JA: Molecular recognition in signal transduction: the interaction surfaces of the SpoOF response regulator with its cognate phosphorelay proteins revealed by alanine scanning mutagenesis. $J \mathrm{Mol}$ Biol 1997, 272(2):200-212.

32. Kim SK, Wilmes-Riesenberg MR, Wanner BL: Involvement of the sensor kinase EnvZ in the in vivo activation of the response-regulator PhoB by acetyl phosphate. Mol Microbiol 1996, 22(1):135-147.

33. Wanner BL: Gene regulation by phosphate in enteric bacteria. J Cell Biochem 1993, 51(1):47-54.

34. Saini DK, Malhotra V, Tyagi JS: Cross talk between DevS sensor kinase homologue, Rv2027c, and DevR response regulator of Mycobacterium tuberculosis. FEBS Lett 2004, 565(1-3):75-80.

35. Roberts DM, Liao RP, Wisedchaisri G, Hol WG, Sherman DR: Two sensor kinases contribute to the hypoxic response of Mycobacterium tuberculosis. J Biol Chem 2004, 279(22):23082-23087. 
36. Stock AM, Robinson VL, Goudreau PN: Two-component signal transduction. Annu Rev Biochem 2000, 69:183-215.

37. Feng J, Atkinson MR, McCleary W, Stock JB, Wanner BL, Ninfa AJ: Role of phosphorylated metabolic intermediates in the regulation of glutamine synthetase synthesis in Escherichia coli. J Bacteriol 1992, 174(19):6061-6070

38. Lukat GS, McCleary WR, Stock AM, Stock JB: Phosphorylation of bacterial response regulator proteins by low molecular weight phospho-donors. Proc Natl Acad Sci U S A 1992, 89(2):718-722.

39. Batchelor E, Walthers D, Kenney LJ, Goulian M: The Escherichia coli CpxACpxR envelope stress response system regulates expression of the porins ompF and ompC. J Bacteriol 2005, 187(16):5723-5731.

40. Birkey SM, Liu W, Zhang X, Duggan MF, Hulett FM: Pho signal transduction network reveals direct transcriptional regulation of one two-component system by another two-component regulator: Bacillus subtilis PhoP directly regulates production of ResD. Mol Microbiol 1998, 30(5):943-953.

41. Wanner BL: Is cross regulation by phosphorylation of two-component response regulator proteins important in bacteria? J Bacteriol 1992, 174(7):2053-2058

42. Dahl JL, Kraus CN, Boshoff HI, Doan B, Foley K, Avarbock D, Kaplan G, Mizrahi V, Rubin H, Barry CE 3rd: The role of RelMtb-mediated adaptation to stationary phase in long-term persistence of Mycobacterium tuberculosis in mice. Proc Natl Acad Sci U S A 2003, 100(17):10026-10031.

43. Betts JC, Lukey PT, Robb LC, McAdam RA, Duncan K: Evaluation of a nutrient starvation model of Mycobacterium tuberculosis persistence by gene and protein expression profiling. Mol Microbiol 2002, 43(3):717-731.

44. Baek JH, Lee SY: Transcriptome analysis of phosphate starvation response in Escherichia coli. J Microbiol Biotechnol 2007, 17(2):244-252.

45. Karakousis PC, Williams EP, Bishai WR: Altered expression of isoniazidregulated genes in drug-treated dormant Mycobacterium tuberculosis. J Antimicrob Chemother 2008, 61(2):323-331.

46. Ahmad Z, Nuermberger EL, Tasneen R, Pinn ML, Williams KN, Peloquin CA, Grosset JH, Karakousis PC: Comparison of the 'Denver regimen' against acute tuberculosis in the mouse and guinea pig. J Antimicrob Chemother 2010, 65(4):729-734

47. Lamichhane G, Zignol M, Blades NJ, Geiman DE, Dougherty A, Grosset J, Broman KW, Bishai WR: A postgenomic method for predicting essential genes at subsaturation levels of mutagenesis: application to Mycobacterium tuberculosis. Proc Natl Acad Sci U S A 2003, 100(12):7213-7218.

48. Klinkenberg $L G$, Lee $J H$, Bishai $W R$, Karakousis PC: The stringent response is required for full virulence of Mycobacterium tuberculosis in guinea pigs. $J$ Infect Dis 2010, 202(9):1397-1404.

49. Thayil SM, Morrison N, Schechter N, Rubin H, Karakousis PC: The role of the novel exopolyphosphatase MT0516 in Mycobacterium tuberculosis drug tolerance and persistence. PLoS One 2011, 6(11):e28076.

50. Karakousis PC, Yoshimatsu T, Lamichhane G, Woolwine SC, Nuermberger EL, Grosset J, Bishai WR: Dormancy phenotype displayed by extracellular Mycobacterium tuberculosis within artificial granulomas in mice. J Exp Med 2004, 200(5):647-657.

51. Manganelli R, Dubnau E, Tyagi S, Kramer FR, Smith I: Differential expression of 10 sigma factor genes in Mycobacterium tuberculosis. Mol Microbiol 1999, 31(2):715-724.

52. Klinkenberg LG, Sutherland LA, Bishai WR, Karakousis PC: Metronidazole lacks activity against Mycobacterium tuberculosis in an in vivo hypoxic granuloma model of latency. J Infect Dis 2008, 198(2):275-283.

\section{Submit your next manuscript to BioMed Central and take full advantage of:}

- Convenient online submission

- Thorough peer review

- No space constraints or color figure charges

- Immediate publication on acceptance

- Inclusion in PubMed, CAS, Scopus and Google Scholar

- Research which is freely available for redistribution 